\title{
Environmental enrichment and intellectual disability: Systematic review of neurocognitive effects in children and adolescents
}

\author{
Orlando Villouta-Gutiérrez ${ }^{1,2 *}$, Cristhian Pérez-Villalobos ${ }^{3}$, Romina Rojas-Ponce ${ }^{4}$, and \\ Fabiola Sáez-Delgado ${ }^{5}$ \\ ${ }^{1}$ Doctorate Program in Mental Health, Faculty of Medicine, Universidad de Concepción; ${ }^{2}$ School of Kinesiology, Faculty of Health, Universidad Santo \\ Tomás; ${ }^{3}$ Department of Medical Education, Faculty of Medicine, Universidad de Concepción; ${ }^{4}$ Department of Pharmacology, Faculty of Biological \\ Sciences, University of Concepción; ${ }^{5}$ Department of Fundamentals of Pedagogy, Faculty of Education, Universidad Católica de la Santísima \\ Concepción. Concepción, Chile
}

\begin{abstract}
Environmental enrichment is a contextual combination of stimuli that facilitate sensory, motor, cognitive, and socioemotional skills. This neuroscientific paradigm enhances experience-dependent neural plasticity, validating it as an intervention model applicable to the educational and neuropsychiatric area in users with intellectual disabilities. The aim is to characterize the neurocognitive effects of environmental enrichment interventions in children and adolescents with intellectual disabilities. A systematic review was conducted according to the guidelines of the PRISMA statement. The search was conducted in Web of Science, Scopus, EBSCOhost, and PubMed databases between 2000 and 2020. Seven studies were selected. Improvements in self-determination, intellectual capacity, social cognition, speech coherence, motor skills, and behavioral regulation were evidenced. The design and execution of the selected protocols are heterogeneous. The application of environmental enrichment protocols in children and adolescents with intellectual disabilities leads to a positive impact on neurocognitive variables.
\end{abstract}

Keywords: Childhood. Environmental enrichment. Intellectual disability. Systematic review. Teens.

\section{Enriquecimiento ambiental y discapacidad intelectual: Revisión sistemática de los efectos neurocognitivos en niños y adolescentes}

\section{Resumen}

El enriquecimiento ambiental es una combinación contextual de estímulos que facilitan las habilidades sensoriales, motoras, cognitivas y socioemocionales. Este paradigma neurocientifico potencia la plasticidad neuronal dependiente de la experiencia, validándola como modelo de intervención aplicable al área educativa y neuropsiquiátrica en usuarios con discapacidad intelectual. El objetivo fue caracterizar los efectos neurocognitivos de las intervenciones de enriquecimiento ambiental en niños y adolescentes con discapacidad intelectual. Se realizó una revisión sistemática de acuerdo con los lineamientos de la declaración PRISMA. La búsqueda se realizó en las bases de datos Web of Science, Scopus, EBSCOhost y PubMed entre 2000 y 2020. Se seleccionaron siete estudios. Se evidenciaron mejoras en la autodeterminación, la capacidad intelectual, la cognición social, la coherencia del habla, las habilidades motoras y la regulación del comportamiento. El diseño y

\section{Correspondence:}

*Orlando Villouta-Gutiérrez

E-mail: ovillouta@udec.cl
Available online: 03-01-2022

Rev Mex Neuroci. 2022;23(1):34-43

www.revmexneurociencia.com

2604-6180 / @ 2021 Academia Mexicana de Neurología A.C. Published by Permanyer. This is an open access article under the CC BY-NC-ND license (http://creativecommons.org/licenses/by-nc-nd/4.0/). 
ejecución de los protocolos seleccionados son heterogéneos. La aplicación de protocolos de enriquecimiento ambiental en niños y adolescentes con discapacidad intelectual conlleva un impacto positivo en las variables neurocognitivas.

Palabras clave: Infancia. Enriquecimiento ambiental. Discapacidad intelectual. Revisión sistemática. Adolescentes.

\section{Introduction}

The varied combination of multimodal sensory stimuli present in environmental enrichment induces biochemical changes that enhance neural plasticity and neuroprotection ${ }^{1}$. This allows an optimal adaptation of the central nervous system to the changing sensory demand of the environment through enhanced morphofunctional reorganization and synaptic consolidation, which optimizes sensory-motor and cognitive-behavioral learning ${ }^{2}$. Therefore, an enriched environment allows generating a zone of well-being where the person interacts in an optimal and novel way with a variability of complex stimuli, generating greater experience-dependent neural plasticity versus traditional stimulation ${ }^{3}$.

The literature defines the environmental enrichment paradigm, from cognitive neuroscience, as a contextual combination of complex inanimate and social stimuli that facilitate sensory, motor, cognitive, and socioemotional skills ${ }^{4}$. This definition focuses on how contextual enrichment can optimize the adaptation and functioning of neural networks, validating it as a potential low-cost intervention model applicable to educational ${ }^{5}$, neurological ${ }^{6}$, and mental health ${ }^{7}$. The transversality of the intervention model is particularly interesting for patients with intellectual disabilities, who may see their performance affected in these three areas.

Intellectual disability is characterized by deficits in cognitive abilities and limitations in the ability to adapt to the environment and social environment ${ }^{8}$, originating before the age of 18 years ${ }^{9}$. Its etiology is varied, encompassing various diagnoses such as unspecified genetic syndromes, Down syndrome, neurodevelopmental disorders, and among others ${ }^{10}$. Environmental enrichment has been shown to be a viable intervention strategy in animal models of intellectual disability ${ }^{11-13}$; however, evidence in human models is still incipiently developing ${ }^{14}$.

In recent years, there have been different review studies that directly or indirectly characterize the effects of environmental enrichment on intellectual disability. There are systematic reviews that highlight the effects of this paradigm on cognitive-behavioral and sensorimotor variables in neurological rehabilitation in adults ${ }^{15}$ and in animal models of acquired brain injury ${ }^{16}$. In turn, there have been narrative reviews on the reaches of environmental enrichment on age-dependent cognitive reserve in animal models ${ }^{17-19}$, on learning in the classroom $^{20}$ and in animal models in intellectual disability ${ }^{11,13}$; however, to date, no systematic review focused on the neurocognitive effects of environmental enrichment in intellectual disability in children and adolescents has been identified.

Therefore, the aim of this article was to characterize the neurocognitive effects of protocolized environmental enrichment interventions in children and adolescents with intellectual disabilities. This will provide reliable and updated information that will allow incorporating the principles of this paradigm in the design of public policies and educational, social, and health interventions.

\section{Method}

An electronic and systematic search of articles was performed following the systematic review methodology based on the international PRISMA guidelines ${ }^{21}$, which was developed in two processes. The first aimed to identify the studies to be included and the second to elaborate a matrix with the purpose of extracting information from the studies for subsequent analysis. The article selection process involved five stages (identification, duplicate, screening, eligibility, and bias) which can be seen graphically in figure 1 .

The identification stage consisted of searching for articles in the Web of Science (WoS), Scopus, EBSCOhost, and PubMed databases using the keywords "environmental enrichment," "intellectual disability," "children," and "teens," their synonyms, extensions, and conjugations, together with the use of Boolean OR and AND terms. A search iteration was performed and the filters specific to each database were applied in relation to the date of publication between January 2000 and October 2020, and type of document article (for syntax used by database, Supplementary Table 1). The final search was performed on October 3, 2020. The duplicate stage consisted of eliminating those studies that had a literal copy of the selected text. The screening stage consisted of a review by two independent judges, who were presented with a protocol to 


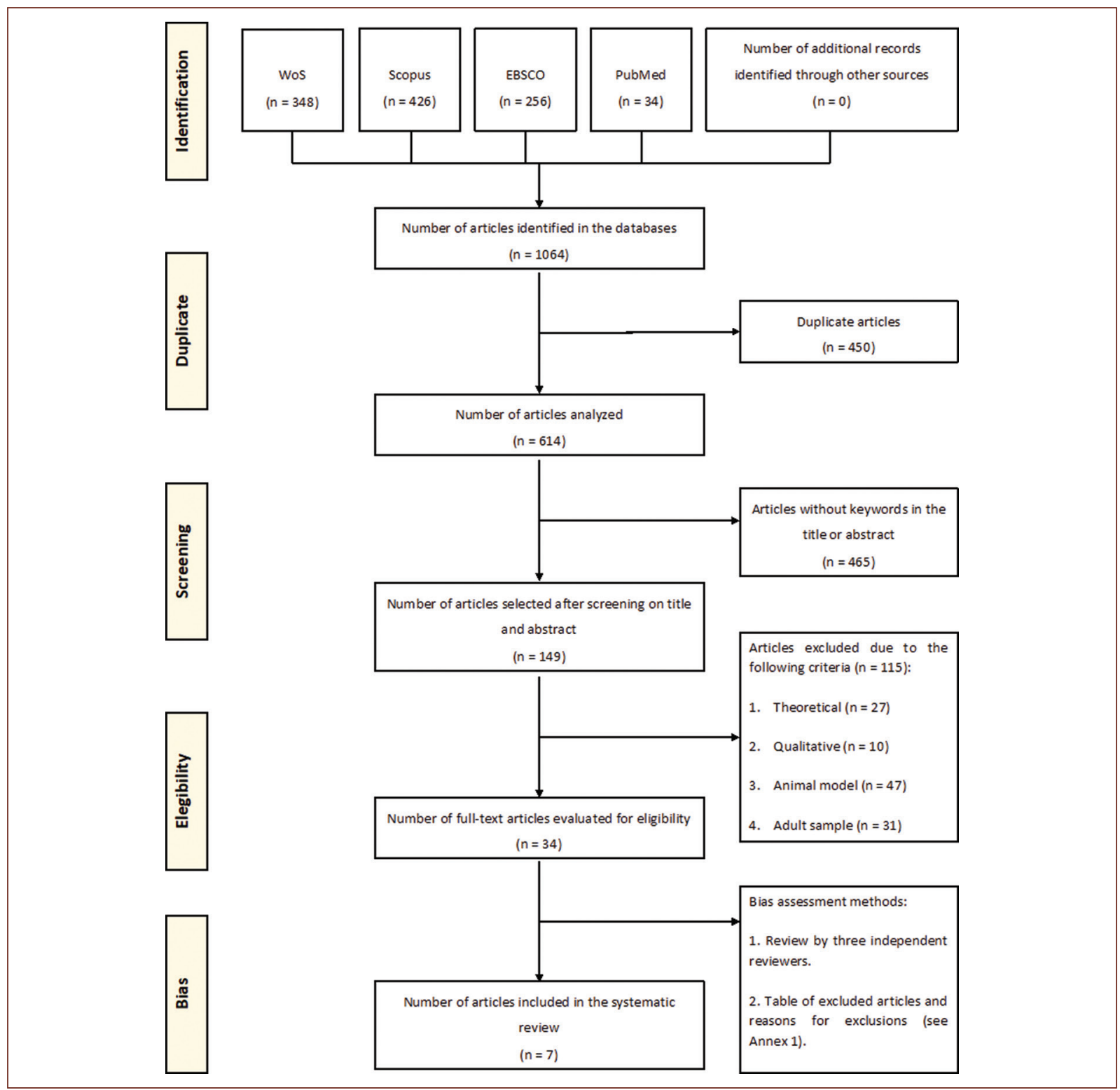

Figure 1. Flow diagram of the search and selection of articles in the study identification process.

evaluate the objective of the review and the keywords to be identified in the title and abstract. Articles that did not contain the key words or did not respond to the objective of this review were eliminated. Articles were also eliminated when two judges considered that they should not be included. Discrepancies were resolved by a third reviewer who decided whether or not to include the article. The eligibility stage involved the downloading and complete reading of the research and the application of the previously established exclusion criteria. Quantitative empirical research that explicitly stated the use of environmental enrichment protocols $^{22}$ in children and adolescents ${ }^{23}$ with intellectual disabilities were included in the study. Exclusion criteria considered were as follows: (1) article not available; (2) case study; (3) language other than Spanish, English or Portuguese; (4) qualitative research; (5) adult research; (6) animal model research; (7) theoretical research; (8) does not specify environmental enrichment; and (9) no diagnosis associated with intellectual disability. The bias assessment stage consisted of the review of the entire process by two independent reviewers, considering the exclusion criteria presented. Finally, the process for the analysis of the information from the included studies ${ }^{24-30}$ involved the aspects described in tables 1 and 2 . 
Table 1. Description of the aspects evaluated in the neurocognitive effects' characterization matrix

\begin{tabular}{|c|c|c|}
\hline ID & Aspect & Description \\
\hline 1 & Article & $\begin{array}{l}\text { Indicates surname(s) of author(s) and } \\
\text { year of publication. }\end{array}$ \\
\hline 2 & Country & $\begin{array}{l}\text { Indicates the country where the study } \\
\text { was carried out. }\end{array}$ \\
\hline 3 & Study design & $\begin{array}{l}\text { Indicates the methodological design of } \\
\text { the study. }\end{array}$ \\
\hline 4 & Participants & $\begin{array}{l}4.1 \text { Indicates the medical diagnosis per } \\
\text { control/experimental group. } \\
4.2 \text { Indicates the age range of the } \\
\text { participants per control/ } \\
\text { experimental group. }\end{array}$ \\
\hline 5 & $\mathrm{n}$ & $\begin{array}{l}\text { Indicates the number of participants } \\
\text { per control/experimental group. }\end{array}$ \\
\hline 6 & $\begin{array}{l}\text { Neurocognitive } \\
\text { variable }\end{array}$ & $\begin{array}{l}\text { Indicates the neurocognitive variable(s) } \\
\text { observed. }\end{array}$ \\
\hline 7 & Instrument & $\begin{array}{l}\text { Indicates the measurement instrument } \\
\text { used to quantify the neurocognitive } \\
\text { variable(s) observed. }\end{array}$ \\
\hline 8 & Effect & $\begin{array}{l}\text { Indicates the results obtained in the } \\
\text { study in relation to the neurocognitive } \\
\text { variable(s) observed. }\end{array}$ \\
\hline
\end{tabular}

\section{Results}

Of the 1064 articles identified in the literature search, 450 were eliminated as duplicates and 465 were excluded at the title and abstract review stage. Of the remaining 149 articles, 115 were excluded due to the following criteria: theoretical study (27), qualitative study (10), animal model study (47), and adult study (31). Thirty-four articles passed to the full-text evaluation stage, where bias evaluation methods were applied with three independent reviewers and the elaboration of a table of excluded articles and reasons for exclusions (Supplementary Table 2). Finally, seven articles were selected for data extraction and analysis of results, through the design of two matrices describing the characterization of neurocognitive effects (Table 3 ) and the characterization of environmental enrichment protocols (Table 4). The process of identification and eligibility of items described above is shown graphically in figure 1.

Of the selected studies, developed in European and American continent, five have an experimental de$\operatorname{sign}^{24-28}$ and two quasi-experimental ${ }^{29,30}$. We identified four free designed, that is, non-patented environmental enrichment protocols that respond to the characterization of a specific sample: Young Director Children's
Table 2. Description of the aspects evaluated in the environmental enrichment protocols' characterization matrix

\begin{tabular}{|l|l|l|}
\hline ID & Aspect & Description \\
\hline 1 & Article & $\begin{array}{l}\text { Indicates surname(s) of author(s) and } \\
\text { year of publication. }\end{array}$ \\
\hline 2 & $\begin{array}{l}\text { Control } \\
\text { protocol }\end{array}$ & $\begin{array}{l}\text { Indicates the protocol used with the } \\
\text { control group. }\end{array}$ \\
\hline 3 & $\begin{array}{l}\text { Experimental } \\
\text { protocol }\end{array}$ & $\begin{array}{l}\text { Indicates the protocol used with the } \\
\text { experimental group. }\end{array}$ \\
\hline 4 & Provider & $\begin{array}{l}\text { Indicates the person in charge of } \\
\text { providing the environmental enrichment. }\end{array}$ \\
\hline 5 & Frequency & $\begin{array}{l}\text { Indicates the number of sessions per } \\
\text { unit of time. }\end{array}$ \\
\hline 6 & Duration & $\begin{array}{l}6.1 \text { Indicates the duration of each } \\
\text { session. }\end{array}$ \\
\hline 7 & Follow-up & $\begin{array}{l}\text { Indicates the duration of the entire } \\
\text { Intervention. }\end{array}$ \\
\hline
\end{tabular}

Animation Studio (YDCA) ${ }^{24}$, Turkish Early Enrichment Project (TEEP) ${ }^{26}$, Project TEAM ${ }^{28}$, and Enriched Environment $A B A B$ Design ${ }^{29}$. In turn, three patented protocols were identified with standardized procedures, independent of sample characterization: Drums Alive Kids Beats $(\mathrm{DAKB})^{25}$, Feuerstein Instrumental Enrichment Basic Program (IE-Basic) ${ }^{27}$, and Program for the Education and Enrichment of Relational Skills $(\text { PEERS })^{30}$. The baseline diagnoses of intellectual disability addressed in the selected articles are subdivided into oligophrenia ${ }^{24}$, unspecified intellectual disability ${ }^{25,29}$, cognitive deficit ${ }^{26,30}$, and neurodevelopmental disorder with cognitive compromise ${ }^{27,28}$. The age range of participants ranged from 3 to 20 years. The neurocognitive variables assessed focus on self-determination $^{28}$, self-efficacy ${ }^{28}$, intellectual ability ${ }^{26,27}$, social cognition ${ }^{25,28,30}$, speech coherence ${ }^{24}$, motor skills ${ }^{25}$, and behavioral regulation ${ }^{25,29}$.

The neurocognitive variables of self-determination, intellectual capacity, and motor skills demonstrated statistically significant improvements on intervention with environmental enrichment protocols compared to control groups without associated environmental enrichment ${ }^{25-27}$. Specifically, in intellectual ability, significant differences were evidenced in abstract reasoning and fluid intelligence ${ }^{27}$, and better long-term academic performance ${ }^{26}$. Social cognition evidenced statistically significant changes following the application of both free 
Rev Mex Neuroci. 2022;23(1)

Table 3. Characterization of neurocognitive effects in the included studies

\begin{tabular}{|c|c|c|c|c|c|c|c|}
\hline Article & Country & Study design & Participants & n & $\begin{array}{l}\text { Neurocognitive } \\
\text { variable }\end{array}$ & Instrument & Effect \\
\hline $\begin{array}{l}\text { Arkhipova } \\
\text { et al. } \\
(2019)^{24}\end{array}$ & Russia & Experimental & $\begin{array}{l}\text { 4.1 CG: } \\
\text { Oligophrenia } \\
\text { EG:Oligophrenia } \\
\text { 4.2 CG: }(9-10) \\
\text { yrs } \\
\text { EG: }(9-10) \text { yrs }\end{array}$ & $\begin{array}{l}\text { CG: } 28 \\
\text { EG: } 28\end{array}$ & $\begin{array}{l}\text { Speech } \\
\text { Coherence }\end{array}$ & $\begin{array}{l}\text { Glukhov } \\
\text { Examination of the } \\
\text { Coherent Speech } \\
\text { Status in Children } \\
\text { with General } \\
\text { Speech } \\
\text { Underdevelopment } \\
\text { (Adapted) }\end{array}$ & $\begin{array}{l}\text { The level of speech } \\
\text { coherence had a } \\
\text { clinical improvement } \\
\text { in the EG, while in } \\
\text { the CG, they } \\
\text { remained unchanged. } \\
\text { Clinical improvements } \\
\text { were evidenced in } \\
\text { speech correctness, } \\
\text { expressiveness and } \\
\text { clarity, vocabulary } \\
\text { enrichment, improved } \\
\text { syntax, and intrinsic } \\
\text { motivation. }\end{array}$ \\
\hline $\begin{array}{l}\text { Ekins } \\
\text { et al. } \\
(2019)^{25}\end{array}$ & Germany & Experimental & $\begin{array}{l}4.1 \text { CG: ID } \\
\text { EG: ID } \\
4.2 \text { CG: } 13.4 \pm \\
1.7 \text { yrs } \\
\text { EG: } 14.2 \pm 3.1 \\
\text { yrs }\end{array}$ & $\begin{array}{l}\text { CG: } 5 \\
\text { EG: } 10\end{array}$ & $\begin{array}{l}\text { Cognitive, } \\
\text { Social, and } \\
\text { Practical } \\
\text { Competencies } \\
\text { Child Behavior } \\
\text { and Emotion } \\
\text { Motor Skills }\end{array}$ & $\begin{array}{l}\text { The Heidelberg } \\
\text { Competency } \\
\text { Inventory (HKI) } \\
\text { Behavior } \\
\text { Questionnaire for } \\
\text { Developmental } \\
\text { Disabilities (VFL-L) } \\
\text { The } \\
\text { Developmental } \\
\text { Behavior Checklist } \\
\text { (DBC) } \\
\text { German Motor } \\
\text { Skill Test (DMT) }\end{array}$ & $\begin{array}{l}\text { HKI with no } \\
\text { significant } \\
\text { differences. DBC } \\
\text { improves individual } \\
\text { behavior patterns of } \\
\text { EG compared to cg } \\
\text { ( } \mathrm{p}=.007 \text { ). VFL-L } \\
\text { improves behavior } \\
\text { significantly ( } \mathrm{p}=.08 \text { ) } \\
\text { in EG compared to } \\
\mathrm{CG} \text { ( } \mathrm{p}=.345 \text { ). DMT } \\
\text { with significant } \\
\text { improvements in EG } \\
\text { in } 5 / 8 \text { motor tasks } \\
\text { assessed, while CG } \\
\text { shows no significant } \\
\text { differences. }\end{array}$ \\
\hline $\begin{array}{l}\text { Kagitcibasi } \\
\text { et al. } \\
(2009)^{26}\end{array}$ & Turkey & Experimental & $\begin{array}{l}\text { 4.1 CG: RCD } \\
\text { EG: RCD } \\
\text { 4.2 CG: }(3-5) \text { yrs } \\
\text { EG: (3-5) yrs }\end{array}$ & $\begin{array}{l}\text { CG: } \\
165 \\
\text { EG: } 90\end{array}$ & $\begin{array}{l}\text { Cognitive } \\
\text { Ability }\end{array}$ & $\begin{array}{l}\text { Operationalization } \\
\text { of cognitive ability } \\
\text { in academic } \\
\text { achievement, } \\
\text { university } \\
\text { attendance, and } \\
\text { vocabulary test } \\
\text { scores. }\end{array}$ & $\begin{array}{l}\text { Developmental } \\
\text { trajectories } \\
\text { indicated that } \\
\text { children whose } \\
\text { pre-intervention CD } \\
\text { were mild to } \\
\text { moderate, but not } \\
\text { severe, benefited } \\
\text { from early EE. A } \\
\text { significantly higher } \\
\text { percentage of the } \\
\text { EG attended } \\
\text { university (44.1\%) } \\
\text { compared to those } \\
\text { in the CG (26.6\%, } \\
\text { p = 0.03). There is a } \\
\text { trend for } \\
\text { participants who } \\
\text { experienced EE in } \\
\text { childhood } \\
\text { (independent of } \\
\text { type) to acquire } \\
\text { higher educational } \\
\text { attainment than } \\
\text { participants who did } \\
\text { not experience } \\
\text { enrichment. }\end{array}$ \\
\hline
\end{tabular}


Table 3. Characterization of neurocognitive effects in the included studies (Continued)

\begin{tabular}{|c|c|c|c|c|c|c|c|}
\hline Article & Country & Study design & Participants & n & $\begin{array}{l}\text { Neurocognitive } \\
\text { variable }\end{array}$ & Instrument & Effect \\
\hline $\begin{array}{l}\text { Kozulin } \\
\text { et al. } \\
(2010)^{27}\end{array}$ & $\begin{array}{l}\text { Italy, } \\
\text { Israel, } \\
\text { Belgium, } \\
\text { Chile } \\
\text { and } \\
\text { Canada }\end{array}$ & Experimental & $\begin{array}{l}\text { 4.1 CG: NDD } \\
\text { EG: NDD } \\
4.2 \text { CG: }(4-20) \\
\text { yrs } \\
\text { EG: }(4-20) \text { yrs }\end{array}$ & $\begin{array}{l}\text { CG: } 49 \\
\text { EG: } 95\end{array}$ & $\begin{array}{l}\text { Intellectual } \\
\text { Capacity }\end{array}$ & $\begin{array}{l}\text { Wechsler } \\
\text { Intelligence Scale } \\
\text { for Children- } \\
\text { Revised (WISC-R) } \\
\text { Raven's } \\
\text { Progressive } \\
\text { Matrices Test }\end{array}$ & $\begin{array}{l}\text { All reevaluated subtest } \\
\text { scores were better in } \\
\text { the EG, with the } \\
\text { difference being } \\
\text { statistically significant } \\
\text { in the "Similarities" ( } p \\
=0.008) \text { " "Incomplete } \\
\text { Figures" ( } p=0.003 \text { ) } \\
\text { and Raven's Matrices } \\
\text { ( } p=0.019 \text { ) subtests. } \\
\text { Fluid intelligence } \\
\text { improves substantially } \\
\text { in children with } C D \\
\text { exposed to the } \\
\text { enrichment program. }\end{array}$ \\
\hline $\begin{array}{l}\text { Kramer } \\
\text { et al. } \\
(2018)^{28}\end{array}$ & $\begin{array}{l}\text { United } \\
\text { States }\end{array}$ & Experimental & $\begin{array}{l}\text { 4.1 CG: NDD } \\
\text { EG: NDD } \\
\text { 4.2 CG: } 17,5 \pm \\
2,3 \text { yrs } \\
\text { EG: } 17,5 \pm 1,8 \\
\text { yrs }\end{array}$ & $\begin{array}{l}\text { CG: } 35 \\
\text { EG: } 47\end{array}$ & $\begin{array}{l}\text { Knowledge } \\
\text { Problem- } \\
\text { Solving } \\
\text { Self- } \\
\text { Determination } \\
\text { Self-Efficacy } \\
\text { Goal } \\
\text { Achievement }\end{array}$ & $\begin{array}{l}\text { Project ASDM } \\
\text { Knowledge and } \\
\text { Problem-Solving } \\
\text { Test } \\
\text { (Project ASDM } \\
\text { Test) } \\
\text { American } \\
\text { Institutes for } \\
\text { Research Self } \\
\text { Determination } \\
\text { Scale (AIR } \\
\text { Self- } \\
\text { determination) } \\
\text { Disability Related } \\
\text { Self-efficacy } \\
\text { Goal Attainment } \\
\text { Scaling }\end{array}$ & $\begin{array}{l}\text { The EG showed } \\
\text { sustained changes in } \\
\text { self-determination and } \\
\text { goal achievement. } \\
\text { There was also } \\
\text { evidence of } \\
\text { significantly higher } \\
\text { knowledge of } \\
\text { environmental barriers } \\
\text { (p<0.001), and a } \\
\text { greater ability to apply } \\
\text { that knowledge to the } \\
\text { achievement of } \\
\text { participatory goals. } \\
\text { There was no } \\
\text { evidence of changes } \\
\text { in self-efficacy. }\end{array}$ \\
\hline $\begin{array}{l}\text { Simó- } \\
\text { Pinatella } \\
\text { et al. } \\
(2019)^{29}\end{array}$ & Spain & $\begin{array}{l}\text { Quasi- } \\
\text { Experimental }\end{array}$ & $\begin{array}{l}\text { 4.1 CG: NA } \\
\text { EG: DI } \\
4.2 \text { CG: NA } \\
\text { EG: } 15,5 \pm \\
1,8 y r s\end{array}$ & $\begin{array}{l}\text { CG: } \\
\text { NA } \\
\text { EG: } 28\end{array}$ & $\begin{array}{l}\text { Challenging } \\
\text { Behavior }\end{array}$ & $\begin{array}{l}\text { Inventory of } \\
\text { Preferred } \\
\text { Activities and } \\
\text { Reinforcers of } \\
\text { Rueda. } \\
\text { Observation/ } \\
\text { Recording Sheet }\end{array}$ & $\begin{array}{l}\text { EE had a significant } \\
\text { impact }(\mathrm{p}<0.05) \text { on } \\
\text { the reduction of the } \\
\text { three challenging } \\
\text { behaviors analyzed: } \\
\text { aggressive, } \\
\text { destructive and } \\
\text { disruptive, with a } \\
\text { greater impact on } \\
\text { disruptive behaviors. }\end{array}$ \\
\hline $\begin{array}{l}\text { Wyman } \\
\text { and Claro. } \\
(2020)^{30}\end{array}$ & Canada & $\begin{array}{l}\text { Quasi- } \\
\text { Experimental }\end{array}$ & $\begin{array}{l}\text { 4.1 CG: NA } \\
\text { GE-1: CD + ASD } \\
\text { GE-2: CD } \\
\text { 4.2 CG: NA } \\
\text { EG-1: (16-21) } \\
\text { yrs } \\
\text { EG-2: (16-21) } \\
\text { yrs }\end{array}$ & $\begin{array}{l}\text { CG: } \\
\text { NA } \\
\text { EG-1: } \\
29 \\
\text { EG-2: } \\
34\end{array}$ & Social Skills & $\begin{array}{l}\text { Test of Adol Social } \\
\text { Skills Knowledge } \\
\text { (TASSK) } \\
\text { Quality of } \\
\text { Socialization } \\
\text { Questionnaire- } \\
\text { Adolescent } \\
\text { (QSQ-A) } \\
\text { Social } \\
\text { Responsiveness } \\
\text { Scale-Second } \\
\text { Edition (SRS-2) } \\
\text { Adult Version }\end{array}$ & $\begin{array}{l}\text { All participants } \\
\text { experienced a } \\
\text { significant } \\
\text { improvement in social } \\
\text { skills ( } p \leq 0.01 \text { ). In } \\
\text { addition, students with } \\
C D \text {, but not those with } \\
\text { ASD, reported a } \\
\text { significant increase in } \\
\text { friendship engagement } \\
\text { ( } p \leq 0.05 \text { ). Overall, the } \\
\text { EE benefited youth } \\
\text { with CD but students } \\
\text { with ASD present } \\
\text { greater challenges in } \\
\text { applying their new } \\
\text { social skills outside of } \\
\text { the program. }\end{array}$ \\
\hline
\end{tabular}

ASD: autism spectrum disorder; CD: cognitive deficit; CG: control group; EE: environmental enrichment; EG: experimental group; ID: intellectual disability; NA: not applicable; NDD: neurodevelopmental disorder; RCD: risk of cognitive deficit; yrs: years. 
Table 4. Characterization of the environmental enrichment protocols of the included studies

\begin{tabular}{|c|c|c|c|c|c|c|}
\hline Article & $\begin{array}{l}\text { Control } \\
\text { protocol }\end{array}$ & Experimental protocol & Provider & Frequency & Duration & Follow-up \\
\hline $\begin{array}{l}\text { Arkhipova } \\
\text { et al. } \\
(2019)^{24}\end{array}$ & $\mathrm{RC}$ & $\begin{array}{l}\text { Young Director Children's } \\
\text { Animation Studio. EE protocol } \\
\text { composed of cartoon creation } \\
\text { classes, literary and creative } \\
\text { classes, visual activities classes, } \\
\text { animation classes and "ABC of } \\
\text { acting and sound" classes. }\end{array}$ & $\begin{array}{l}\text { Interdisciplinary } \\
\text { team composed of } \\
\text { language } \\
\text { teachers, } \\
\text { computer teachers } \\
\text { and graphic } \\
\text { designers }\end{array}$ & NR & $\begin{array}{l}6.1 \mathrm{NR} \\
6.2 \mathrm{NR}\end{array}$ & NR \\
\hline $\begin{array}{l}\text { Ekins } \\
\text { et al. } \\
(2019)^{25}\end{array}$ & $\begin{array}{l}\text { Physical } \\
\text { education RC }\end{array}$ & $\begin{array}{l}\text { Physical education RC in } \\
\text { combination with Drums Alive }{ }^{\circledR} \\
\text { Kids Beats sessions. EE protocol } \\
\text { composed of rhythmic percussion, } \\
\text { music, movement and cognition } \\
\text { through a cross-curricular } \\
\text { approach that enhances creativity } \\
\text { and critical thinking. }\end{array}$ & Trained teachers & $\begin{array}{l}2 \text { physical } \\
\text { education } \\
\mathrm{RC}+2 \\
\text { sessions of } \\
\text { EE/wk }\end{array}$ & $\begin{array}{l}6.1 \mathrm{NR} \\
6.27 \mathrm{wk}\end{array}$ & NR \\
\hline $\begin{array}{l}\text { Kagitcibasi } \\
\text { et al. } \\
(2009)^{26}\end{array}$ & $\begin{array}{l}\text { No educational } \\
\text { intervention } \\
\text { with } \mathrm{EE}\end{array}$ & $\begin{array}{l}\text { Educational Intervention Turkish } \\
\text { Early Enrichment Project (TEEP). } \\
\text { Home and educational center EE } \\
\text { protocol for preschool children. } \\
\text { Composed of three options: } \\
\text { educational nursery, day care } \\
\text { center, and home. These three } \\
\text { options are accompanied by } \\
\text { mother's education. }\end{array}$ & Trained staff & $\begin{array}{l}60 \text { educative } \\
\text { sessions in } \\
2 \text { yrs }\end{array}$ & $\begin{array}{l}6.1 \mathrm{NR} \\
6.22 \mathrm{yrs}\end{array}$ & 7 y 19 yrs \\
\hline $\begin{array}{l}\text { Kozulin } \\
\text { et al. } \\
(2010)^{27}\end{array}$ & $\begin{array}{l}\text { Occupational } \\
\text { therapy, } \\
\text { sensory-motor } \\
\text { training and RC }\end{array}$ & $\begin{array}{l}\text { Feuerstein Instrumental } \\
\text { Enrichment (IE) Basic Program }{ }^{\circledR} \\
\text { (Adapted). EE protocol focused on } \\
\text { transforming passive and } \\
\text { dependent students into more } \\
\text { active and self-motivated learners. } \\
\text { Composed of } 6 / 9 \text { items aimed at } \\
\text { enhancing mathematical skills, } \\
\text { literacy, and social interaction. }\end{array}$ & Trained teachers & $\begin{array}{l}90 \mathrm{~h} \text { in } \\
30-45 \mathrm{wk}\end{array}$ & $\begin{array}{l}6.145-90^{\prime} \\
6.230-45 \\
\text { wk }\end{array}$ & NR \\
\hline $\begin{array}{l}\text { Kramer } \\
\text { et al. } \\
(2018)^{28}\end{array}$ & $\begin{array}{l}\text { Mentor, parent } \\
\text { and peer- } \\
\text { guided } \\
\text { planning and } \\
\text { execution of a } \\
\text { participant- } \\
\text { defined } \\
\text { community trip }\end{array}$ & $\begin{array}{l}\text { Project ASDM. Multicomponent } \\
\text { EE protocol that includes } \\
\text { individualized goal setting, group } \\
\text { curriculum, and peer mentoring. } \\
\text { Each component of the } \\
\text { intervention implements problem- } \\
\text { solving skills, self-efficacy, } \\
\text { self-determination, and } \\
\text { participation, with the goal of } \\
\text { identifying and resolving physical } \\
\text { and social environmental barriers } \\
\text { to social engagement }\end{array}$ & $\begin{array}{l}\text { Social worker and } \\
\text { trained tutors }\end{array}$ & 2 sessions/wk & $\begin{array}{l}6.1120^{\prime} \\
6.212 \mathrm{wk}\end{array}$ & 6 wk \\
\hline $\begin{array}{l}\text { Simó- } \\
\text { Pinatella } \\
\text { et al. } \\
(2019)^{29}\end{array}$ & NA & $\begin{array}{l}\text { Enriched Environment } A B A B \\
\text { Design. EE protocol composed of } \\
4 \text { phases of } 5 \text { sessions each: } 1-A \\
\text { baseline without EE. 2-B EE in a } \\
\text { playground with a variety of } \\
\text { activities. } 3-A^{*} \text { again baseline } \\
\text { without EE. } 4-B^{*} \text { again EE }\end{array}$ & $\begin{array}{l}\text { Tutors and } \\
\text { monitors }\end{array}$ & $\begin{array}{l}5 \text { sessions/wk } \\
\text { (Phase } 2 \text { y } 4 \text { ) }\end{array}$ & $\begin{array}{l}6.160^{\prime} \\
6.22 \mathrm{wk} \\
\text { (Fase } \\
2 \text { y } 4 \text { ) }\end{array}$ & NR \\
\hline $\begin{array}{l}\text { Wyman } \\
\text { and Claro. } \\
(2020)^{30}\end{array}$ & NA & $\begin{array}{l}\text { Program for the Education and } \\
\text { Enrichment of Relational Skills }{ }^{\circledR} \\
\text { (PEERS). Curriculum-based EE } \\
\text { protocol that enhances social } \\
\text { and behavioral skills by providing } \\
\text { real-world experiences that allow } \\
\text { students to project acquired } \\
\text { social skills into real life. }\end{array}$ & $\begin{array}{l}\text { PhD student in } \\
\text { Educational } \\
\text { Psychology and } \\
\text { trained teachers. }\end{array}$ & 2 sessions/wk & $\begin{array}{l}6.145^{\prime} \\
6.216 \mathrm{wk}\end{array}$ & 2 wk \\
\hline
\end{tabular}

EE: environmental enrichment; NA: not applicable; NR: no report; RC: regular classes; wk: weeks; ‘: minutes. 
designed $^{28}$ and patented ${ }^{25,30}$ environmental enrichment protocols. In behavioral regulation, a significant decrease in aggressive, destructive, and disruptive behaviors was observed following exposure to free designed $^{29}$ and patented ${ }^{25}$ environmental enrichment. Speech coherence clinically improved in the experimental group exposed to environmental enrichment compared to the control group without associated enrichment, mainly in the subvariables of correctness, expressiveness and clarity of speech, vocabulary enrichment, syntax, and intrinsic motivation ${ }^{24}$. No clinically significant changes in self-efficacy were present in the selected studies ${ }^{28}$.

In relation to the design and implementation of environmental enrichment protocols, both the provider profiles, the frequency of intervention and the duration of intervention per session and overall, present high heterogeneity. Providers include trained teachers ${ }^{25,26,30}$, tutors and trained monitors without specifying profes$\operatorname{sion}^{26,28,29}$, and interdisciplinary teams ${ }^{24}$. Intervention frequencies varied between two sessions ${ }^{25,28,30}$ and five sessions ${ }^{29}$ weekly with a duration between $45 \mathrm{~min}^{27,30}$ and $120 \mathrm{~min}^{28}$. The total duration of the protocols varied from 2 to 7 weeks in targeted interventions ${ }^{25,29,30}$, to 1 to 2 years in long-term interventions ${ }^{26,27}$. Only three studies specified follow-up of participants between 2 and 6 weeks ${ }^{28,30}$ up to 19 years ${ }^{26}$.

\section{Discussion}

The aim of this systematic review was to characterize the neurocognitive effects of protocolized environmental enrichment interventions in children and adolescents with intellectual disabilities. For such purposes, first, we must differentiate environmental enrichment as a neuroscientific paradigm from enriched therapy or intervention. Environmental enrichment, as proposed by Heidi Janssen, involves creating experiences in which participants can engage in social, cognitive, and sensorimotor activities simultaneously ${ }^{31}$. This allows for increased opportunities for practice and promotes active participation ${ }^{32}$. Environmental enrichment merges with activities of daily life and social participation specific to the user's everyday life ${ }^{33}$, therefore, there are programs contextualized in specific educational, work, or leisure realities. In contrast, the enriched intervention involves the enhancement of a unique dimension, not necessarily fulfilling the simultaneity among the four dimensions proposed by the neuroscientific model. In the enriched intervention, the participant can be an active or passive agent, and the activity is not necessarily designed in a situational context attentive to the user's reality 22 .

The results of this research demonstrate positive effects of environmental enrichment on different neurocognitive dimensions compared to controls without enrichment in children and adolescents with intellectual disabilities, which is justified based on findings in the field of cognitive neuroscience and neurobiology. These disciplines have demonstrated that the environmental enrichment paradigm induces varied neural plasticity responses in the central nervous system in both animal and human models, ranging from functional cognitive enhancement to potentiation of synaptic plasticity, adult hippocampal neurogenesis, synaptogenesis, and modulation of gene expression ${ }^{34,35}$. The diversity of multimodal sensory inputs implicit in environmental enrichment induce epigenetic changes that enhance neural plasticity and neuroprotection through upregulation of glutamatergic and GABAergic tone, and upregulation of angioglioneurins such as BDNF, NGF, IGF-1, VEGF, and EPO ${ }^{36}$.

The horizontal improvement of different neurocognitive variables through environmental enrichment protocols not only sustains an improvement in the cognitive functioning of children and adolescents with intellectual disabilities but, in turn, also provides them with tools based on the contextual practice of activities of daily living and social participation that facilitate their effective educational, labor, and social inclusion. In fact, social models of inclusion theoretically respond to the paradigm of environmental enrichment, as it implies the interaction of sensory, motor, cognitive, and socioemotional factors ${ }^{37}$. The intrinsic contextualization of the paradigm to the situational reality of the participants encourages the development of neurocognitive dimensions applied to the context itself, which facilitates its extrapolation to the user's daily life.

The only neurocognitive variable that did not show positive changes was self-efficacy. Self-efficacy is defined as a person's belief in his or her ability to achieve certain actions, which will influence thoughts about him or herself ${ }^{38}$. It is interesting to hypothesize why self-efficacy did not improve in adolescents with intellectual disabilities who participated in the Project Team proto$\mathrm{col}^{28}$. The study suggests that the non-variation in self-efficacy responds to the characteristics of the assessment instrument used; however, let us recall that children and adolescents with intellectual disabilities make external attributions of their successes ("I did well just by luck") and internal attributions of their failures ("I'm just slow") mainly due to a history of failed experiences with the environment. This makes them internalize 
a negative self-image and develop lower self-efficacy ${ }^{39}$, which in adolescence may be less susceptible to change.

In this study, it can be observed that the design and execution of the environmental enrichment protocols are irregular at the time of establishing providers, frequency and duration. The provider of environmental enrichment is not technically defined, since, strictly speaking, the multimodality of the model and the range of contextual applications imply the formation of inter- and transdisciplinary teams for its optimal design and execution. The disparity in the frequency and duration of the sessions unfortunately responds to the lack of consensus in the literature on the methodological design and dosage of environmental enrichment paradigms ${ }^{40}$, which is still a matter of research.

This systematic review presents a number of methodological limitations, such as including only papers published in English, Spanish, and Portuguese. The varied etiology of intellectual disability also represents a limitation per se, as it increases the plurality of the sample of studies analyzed. In addition, the methodological design, the environmental enrichment protocols, and the neurocognitive variables evaluated are heterogeneous, respond to different situational contexts, and include the baseline bias of the instruments used to evaluate.

\section{Conclusions}

The application of environmental enrichment protocols in children and adolescents with intellectual disabilities has a positive impact on neurocognitive variables associated with intelligence, communication, socialization, and motor skills. The environmental enrichment paradigm is supported by scientific evidence in animal and human models. In turn, its guidelines encourage effective inclusion in activities of daily living and social participation of participants; however, it has methodological limitations that should be addressed in future research.

This systematic review is projected as a prelude to future research to better elucidate the benefits of environmental enrichment in intellectual disabilities. This will allow the foundation of base guidelines for public policies and programs of social, educational, labor, and health intervention that favor this profile of patients.

\section{Funding}

This work was funded by the National Agency for Research and Development (ANID)/Scholarship Program/Beca Doctorado Nacional/2020-21201270.

\section{Conflicts of interest}

The authors declare that they have no conflicts of interest.

\section{Ethical responsibilities}

Protection of humans and animals. The authors declare that no experiments on humans or animals have been performed for this research.

Confidentiality of data. The authors declare that no patient data appear in this article.

Right to privacy and informed consent. The authors declare that no patient data appear in this article.

\section{SUPPLEMENTARY DATA}

Supplementary data are available at DOI: $10.24875 /$ RMN.21000012. These data are provided by the corresponding author and published online for the benefit of the reader. The contents of supplementary data are the sole responsibility of the authors.

\section{References}

1. Sale A, Berardi N, Maffei L. Environment and brain plasticity: towards an endogenous pharmacotherapy. Physiol Rev. 2014;94:189-234.

2. Clemenson GD, Gage FG, Stark CE. Environmental enrichment and neuronal plasticity. In: Chao M, editor. The Oxford Handbook of Developmental Neural Plasticity. New York: Oxford University Press; 2017. p. 1-42.

3. Hannan AJ. Review: environmental enrichment and brain repair: harnessing the therapeutic effects of cognitive stimulation and physical activity to enhance experience-dependent plasticity. Neuropathol Appl Neurobiol. 2014;40:13-25.

4. Morgan C, Novak I, Badawi N. Enriched environments and motor outcomes in cerebral palsy: systematic review and meta-analysis. Pediatrics. 2013;132:735-46.

5. Liu M. Examining the performance and attitudes of sixth graders during their use of a problem-based hypermedia learning environment. Comput Hum Behav. 2004;20:357-79.

6. Rosbergen IC, Grimley RS, Hayward KS, Walker KC, Rowley D, Campbell $\mathrm{AM}$, et al. Embedding an enriched environment in an acute stroke unit increases activity in people with stroke: a controlled before-after pilot study. Clin Rehabil. 2017;31:1516-28.

7. Maitland DW, Neilson EC, Munoz EA, Ybanez A, Murray AL. The impact of an enriched environment on the relationship between activation and depression in latinx and non-latinx students. Psychol Rec. 2019;69:541-50.

8. Iwase S, Berube NG, Zhou ZL, Kasri NN, Battaglioli E, Scandaglia M, et al. Epigenetic etiology of intellectual disability. J Neurosci. 2017;37:10773-82.

9. Caballero Pérez V, López Pisón FJ, Miramar Gallart MD, González Álvarez A, García Jiménez MC, García Iñiguez JP, et al. Phenotype in patients with intellectual disability and pathological results in array CGH. Neurologia. 2017;32:568-78.

10. López-Pisón J, García-Jiménez MC, Monge-Galindo L, Lafuente-Hidalgo M, Pérez-Delgado R, García-Oguiza A, et al. Our experience with the aetiological diagnosis of global developmental delay and intellectual disability: 2006-2010. Neurologia. 2014;29:402-7.

11. De Giorgio A. The roles of motor activity and environmental enrichment in intellectual disability. Somatosens Mot Res. 2017;34:34-43.

12. Laviola G, Hannan AJ, Macrì S, Solinas M, Jaber M. Effects of enriched environment on animal models of neurodegenerative diseases and psychiatric disorders. Neurobiol Dis. 2008;31:159-68.

13. Toma ID, Gil LM, Ossowski S, Dierssen M. Where environment meets cognition: a focus on two developmental intellectual disability disorders. Neural Plast. 2016;2016:4235898. 


\section{O. Villouta-Gutiérrez et al.: Environmental enrichment and intellectual disability}

14. Ball NJ, Mercado E, Orduna I. Enriched environments as a potential treatment for developmental disorders: a critical assessment. Front Psychol. 2019;10:12.

15. Reid I, Ng L, Khan F. Environmental enrichment for adults with neurological conditions: a systematic review. Int J Ther Rehabil. 2016;23: 423-31.

16. Mala $\mathrm{H}$, Rasmussen $\mathrm{CP}$. The effect of combined therapies on recovery after acquired brain injury: systematic review of preclinical studies combining enriched environment, exercise, or task-specific training with other therapies. Restor Neurol Neurosci. 2017;35:25-64

17. Gelfo F, Mandolesi L, Serra L, Sorrentino G, Caltagirone C. The neuroprotective effects of experience on cognitive functions: evidence from animal studies on the neurobiological bases of brain reserve. Neuroscience. 2018;370:218-35.

18. Montero-Herrera B. Evidence coming from animal model studies about exercise effects and environmental enrichment on adults neurogenesis. Rev Mex Neuroci. 2018;19:53-69.

19. Mora-Gallegosa A, Salas S, Fornaguera-Tríasa J. Effects of age-dependent environmental enrichment on behavior, cognitive functions and neurochemistry. Rev Mex Neuroci. 2017;18:66-78.

20. Marió Casanova A, Contreras Paredes N, Jiménez Oliveira B. Educating in an Enriched environment: because we are all connected. Rev Chil Neuropsicol. 2018;13:1-5.

21. Moher D, Shamseer L, Clarke M, Ghersi D, Liberati A, Petticrew M, et al. Preferred reporting items for systematic review and meta-analysis protocols (PRISMA-P) 2015 statement. Syst Rev. 2015;4:1-9.

22. Natali F, Difranco C, Gatti R. Enriched environment or enriched therapy? Time for clarification. Physiother Theory Pract. 2020;36:1175-8.

23. McDonagh JE, European Training Effective Care and Health Faculty. The age of adolescence... and young adulthood. Lancet Child Adolesc Health. 2018;2:e6.

24. Arkhipova SV, Grishina OS, Minaeva NG, Mikheikina TA, Ryabova NV. The formation of the coherent speech of junior schoolchildren with intellectual disabilities by means of animation-based therapy. Rev Incl. 2019;6:47-62.

25. Ekins C, Wright J, Schulz H, Wright PR, Owens D, Miller W. Effects of a Drums alive $(R)$ kids beats intervention on motor skills and behavior in children with intellectual disabilities. Palaestra. 2019;33:16-25.

26. Kagitcibasi C, Sunar D, Bekman S, Baydar N, Cemalcilar Z. Continuing effects of early enrichment in adult life: the Turkish early enrichment project 22 years later. J Appl Dev Psychol. 2009;30:764-79.

27. Kozulin A, Lebeer J, Madella-Noja A, Gonzalez F, Jeffrey I, Rosenthal N, et al. Cognitive modifiability of children with developmental disabilities: a multicentre study using Feuerstein's instrumental enrichment-basic program. Res Dev Disabil. 2010;31:551-9.
28. Kramer JM, Helfrich C, Levin M, Hwang IT, Samuel PS, Carrellas A, et al Initial evaluation of the effects of an environmental-focused problem-solving intervention for transition-age young people with developmental disabilities: project TEAM. Dev Med Child Neurol. 2018;60:801-9.

29. Simó-Pinatella D, Rodrigo Parral G, Dolado Guivernau R. Effects of structured playground activities on the challenging behavior of youth with intellectual disabilities. Rev Esp Discapac. 2019;7:29-41.

30. Wyman J, Claro A. The UCLA PEERS school-based program: treatment outcomes for improving social functioning in adolescents and young adults with autism spectrum disorder and those with cognitive deficits. J Autism Dev Disord. 2020;50:1907-20.

31. Janssen H, Ada L, Bernhardt J, McElduff P, Pollack M, Nilsson M, et al. An enriched environment increases activity in stroke patients undergoing rehabilitation in a mixed rehabilitation unit: a pilot non-randomized controlled trial. Disabil Rehabil. 2014;36:255-62.

32. Khan F, Amatya B, Elmalik A, Lowe M, Ng L, Reid I, et al. An enriched environmental programme during inpatient neuro-rehabilitation: a randomized controlled trial. J Rehabil Med. 2016;48:417-25.

33. Ng L, Reid I, Gorelik A, Galea M, Khan F. Environmental enrichment fo stroke and other non-progressive brain injury. Cochrane Database Syst Rev. 2015;2015:CD011879.

34. Martinez-Morga M, Martinez S. Neuroplasticity: synaptogenesis during normal development and its implication in intellectual disability. Rev Neurol. 2017;64:S45-50.

35. Pang TY, Hannan AJ. Enhancement of cognitive function in models of brain disease through environmental enrichment and physical activity. Neuropharmacology. 2013;64:515-28.

36. Lafuente JV, Bengoetxea H, Ortuzar N, Bulnes S. Angioglioneurins and environmental enrichment, enhancing neuroprotection. In: García-Rodríguez JC, editor. Neuroprotection in Neurodegenerative and Hereditary Degenerative Diseases. Barcelona: OmniaScience, 2014, p. 209-257.

37. Willis J. Success for all students in inclusion classes. In: Willis J, editor. Brain-Friendly Strategies for the Inclusion Classroom: insights from a Neurologist and Classroom Teacher. Virginia: Association for Supervision and Curriculum Development; 2007. p. 11-50.

38. Bandura A. On the functional properties of perceived self-efficacy revisited. J Manage. 2012;38:9-44

39. Caso-Fuertes AM, García-Sánchez J. How to improve self-efficacy towards writing in children with borderline intellectual disabilities. Int $J$ Educ Dev. 2005;2:625-32.

40. McDonald MW, Hayward KS, Rosbergen IC, Jeffers MS, Corbett D. Is environmental enrichment ready for clinical application in human poststroke rehabilitation? Front Behav Neurosci. 2018;12:135. 